\title{
AKRUAL
}

Jurnal Akuntansi

http://journal.unesa.ac.id/php.index/aj

\section{PENGARUH PAD, DAU, DAK TERHADAP PERTUMBUHAN EKONOMI DENGAN BELANJA MODAL SEBAGAI VARIABEL INTERVENING}

\author{
Pungky Siswiyanti \\ Universitas Negeri Surabaya \\ Siswiyantipungky@ymail.com
}

\begin{abstract}
The purpose of this study was to determine the effect of PAD, DAU, DAK to Economic Growth with Capital Expenditure as an intervening variable. Data was from the local budget realization report and the GDP report. The study period was during 2012-2014. Analysis of the data used in this study is Path Analysis. The analysis showed the the PAD, DAU positive effect on Economic Growth. While DAK negatively effect to Economic Growth. And the result of the analysis also showed that Capital Expenditure can be used as an intervening variable (mediation) the relationship between PAD and Economic Growth.

Keywords: PAD, DAU, DAK, Economic Growth, Capital Expenditure,PDRB
\end{abstract}

\section{PENDAHULUAN}

Dengan adanya otonomi daerah, pemerintah daerah diharapkan semakin mandiri, mengurangi ketergantungan terhadap pemerintah pusat baik dalam hal pembiayaan pembangunan maupun dalam hal pengelolaan keuangan daerah. Pembangunan infrastruktur di suatu daerah sangat mempengaruhi laju perekonomian daerah. Secara tidak langsung pertumbuhan ekonomi juga dipengaruhi oleh pembangunan infrastruktur. Sesuai dengan Teori Pertumbuhan Endogen yang menyatakan bahwa salah satu sumber pertumbuhan adalah peningkatan akumulasi modal. Maqin (2011) di Jawa Barat dengan hasil penelitian infrastruktur listrik, tenaga kerja, dan pengeluaran mempunyai pengaruh positif dan signifikan terhadap pertumbuhan ekonomi. Sehingga secara tidak langsung Belanja Modal berperan terhadap laju Pertumbuhan Ekonomi di suatu daerah. Semakin tinggi tingkat investasi modal diharapkan mampu meningkatkan kualitas dan kuantitas layanan publik, karena aset tetap yang dimiliki sebagai akibat adanya belanja modal merupakan prasyarat utama dalam memberikan pelayanan publik oleh pemerintah daerah. Tersedianya infrastruktur yang baik diharapkan dapat menciptakan efisiensi dan efektifitas di berbagai sektor serta meningkatkan produktifitas masyarakat yang akan meningkatkan pertumbuhan ekonomi yaitu proses kenaikan output perkapita dalam jangka panjang. Felix (2012) berpendapat bahwa pemerintah daerah semestinya dapat mengalokasikan belanja modal lebih tinggi dibandingkan belanja rutin yang relative 
kurang produktif. Tetapi dalam prakteknya masih banyak daerah yang memiliki anggaran belanja modal lebih rendah dibandingkan dengan belanja pegawai ini terlihat dari laporan realisasi anggaran kab/kota di Jawa Timur dari tahun 2012-2013. Dengan meningkatnya pengeluaran modal diharapkan dapat meningkatkan kualitas dan kuantitas pelayanan publik karena hasil dari pengeluaran belanja modal adalah meningkatnya aset tetap daerah yang merupakan prasyarat dalam memberikan pelayanan publik oleh pemerintah daerah. Mardiasmo (2009:30) mengatakan bahwa semakin tinggi tingkat belanja modal diharapkan mampu meningkatkan tingkat partisipasi (kontribusi) publik terhadap pembangunan yang tercermin dari adanya peningkatan PAD.

Provinsi Jawa Timur memiliki skala pertumbuhan ekonomi lebih besar dibanding pertumbuhan ekonomi nasional. Berdasarkan Gambar 1.1 perkembangan pertumbuhan ekonomi Jawa Timur pada tahun 2012-2014 selalu lebih tinggi dibandingkan dengan pertumbuhan ekonomi Nasional. Dan dapat dilihat juga bahwa terjadi penurunan pada tingkat pertumbuhan ekonomi di Jawa Timur tetapi tetap diatas pertumbuhan ekonomi Nasional.

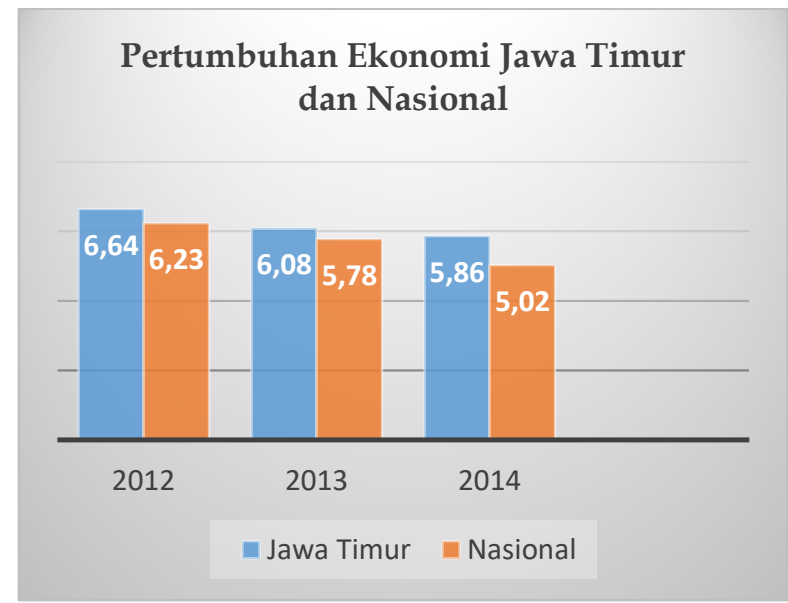

Sumber: BPS Provinsi Jawa Timur

\section{Gambar 1.1 Pertumbuhan Ekonomi Jawa Timur dan Nasional}

Berdasarkan permasalahan diatas maka peneliti perlu mengkaji ulang untuk melakukan penelitian yang berjudul " Pengaruh Pendapatan Asli Daerah (PAD), Dana Alokasi Umum (DAU), Dana Alokasi Khusus (DAK) Terhadap Pertumbuhan Ekonomi Dengan Belanja Modal Sebagai Variabel Intervening" (Studi Empiris pada Pemerintah Provinsi Jawa Timur Tahun 2012-2014). 


\section{KAJIAN PUSTAKA}

\section{Desentralisasi}

Menurut UU Nomor 5 Tahun 1974 desentralisasi adalah penyerahan urusan pemerintah dari pusat kepada daerah. Pelimpahan wewenang kepada Pemerintahan Daerah, sematamata untuk mencapai suatu pemerintahan yang efisien. Pelimpahan wewenang tersebut menghasilkan otonomi. Otonomi itu sendiri adalah kebebasan masyarakat yang tinggal di daerahnya itu sendiri untuk mengatur dan mengurus kepentingannya sendiri. Bentuk aplikasi desentralisasi adalah otonomi, kewenangan dan tanggung jawab menjadi milik daerah itu sendiri, baik dari segi implementasi kebijakan, perencanaan dan pendanaan. Dengan adanya desentralisasi maka daerah memiliki kewenangan penuh terhadap tata kelola pemerintahannya sendiri. Diharapkan pemerintah daerah mampu mengoptimalkan kemampuan daerahnya untuk melakukan pembiayaan di daerahnya seperti PAD, DAU dan DAK.

Menurut UU No. 25 tahun 1999, PAD merupakan semua penerimaan daerah yang berasal dari potensi sumber daya yang ada di daerah. Sumber-sumber PAD meliputi hasil pajak daerah, hasil retribusi daerah, hasil perusahaan milik daerah dan hasil pengelolaan kekayaan daerah lainnya yang dipisahkan, lain-lain pendapatan asli daerah yang sah. Selain mengelola penerimaan yang berasal dari daerahnya sendiri, pemerintah daerah juga menerima dan mengelola dana yang bersumber dari APBN pemerintah pusat. Dana perimbangan tersebut adalah DAU, DAK. DAU dialokasikan dalam bentuk Block Grant yakni hibah penggunaannya cukup fleksibel (tidak banyak larangan) seperti halnya hibah kategori (Sutedi Adrian, 2012:143). Hibah ini dapat digunakan untuk banyak tujuan sesuai dengan kebutuhan. Dana alokasi umum merupakan jenis transfer dana antar tingkat pemerintahan yang tidak terikat dengan program pengeluaran tertentu. Adapun tujuan dari transfer ini adalah untuk menutup kesenjangan fiskal (fiscal gap) dan pemerataan kemampuan fiskal antar daerah sehingga dana alokasi umum tiap daerah tidak akan sama besarnya. Dana alokasi khusus (DAK) adalah dana yang berasal dari APBN, yang dialokasikan kepada daerah untuk membantu membiayai kebutuhan khusus, alokasi DAK ditentukan dengan memperhatikan tersedianya dana dalam APBN (Sutedi Adrian,2012:145). 


\section{Teori Pertumbuhan Endogen}

Teori Pertumbuhan Endogen (Endogenous Growth) atau dengan kata yang lebih sederhana, teori Pertumbuhan Baru (New Growth Theory). Teori pertumbuhan endogen berusaha menjelaskan bahwa sumber-sumber pertumbuhan adalah peningkatan akumulasi modal dalam arti yang luas (Michael P. Todaro, 2006:172). Modal dalam hal ini tidak hanya dalam sifat fisik tetapi juga yang bersifat non-fisik berupa ilmu pengetahuan dan teknologi.

Secara umum pertumbuhan ekonomi dapat diartikan perkembangan perekonomian yang menyebabkan barang dan jasa yang diproduksi dalam masyarakat bertambah dan kemakmuran masyarakat meningkat. Pertumbuhan ekonomi merupakan kenaikan PDRB tanpa memandang apakah kenaikan itu lebih besar ataukah lebih kecil dari tingkat pertumbuhan penduduk atau dalam perubahan struktur ekonomi berlaku atau tidak. Produk Domestik Regional Bruto (PDRB) adalah jumlah nilai tambah barang dan jasa yang dihasilkan dari seluruh kegiatan perekonomian di suatu daerah. Penghitungan PDRB atas harga yaitu harga berlaku dan harga konstan. PDRB atas harga berlaku merupakan nilai tambah barang dan jasa yang dihitung menggunakan harga yang berlaku pada tahun bersangkutan, sementara PDRB atas dasar harga konstan dihitung dengan menggunakan harga pada tahun tertentu sebagai tahun dasar. Sukirno (2006:9-10) juga mengatakan bahwa pertumbuhan ekonomi sebagai ukuran kuantitatif yang menggambarkan perkembangan suatu perekonomian dalam suatu tahun tertentu apabila dibandingkan tahun sebelumnya

\section{Belanja Modal dalam Anggaran Belanja}

Belanja modal merupakan pengeluaran anggaran untuk perolehan aset tetap dan aset lainnya yang memberi manfaat lebih dari satu periode akuntansi (Halim, 2014:107). Menurut PP Nomor 71 Tahun 2010, belanja modal merupakan belanja Pemerintah Daerah yang manfaatnya melebihi satu tahun anggaran dan akan menambah aset atau kekayaan daerah dan selanjutnya akan menambah belanja yang bersifat rutin seperti biaya pemeliharaan pada kelompok belanja administrasi umum. Belanja Modal dapat dikategorikan dalam 5 kategori utama:

1. Belanja Modal Tanah

2. Belanja Modal Peralatan dan Mesin 
3. Belanja Modal Gedung dan Bangunan

4. Belanja Modal Jalan, Irigasi, dan Jaringan

5. Belanja Modal Fisik Lainnya

\section{HIPOTESIS}

Dari uraian pendahuluan di atas, maka dapat ditarik beberapa hipotesis dibawah ini:

H1 = PAD berpengaruh terhadap Pertumbuhan Ekonomi

$\mathrm{H} 2=\mathrm{DAU}$ berpengaruh terhadap Pertumbuhan Ekonomi

H3 = DAK berpengaruh terhadap Pertumbuhan Ekonomi

$\mathrm{H} 4=$ PAD berpengaruh terhadap Pertumbuhan Ekonomi dengan Belanja Modal sebagai Variabel Intervening

\section{METODE}

\section{Jenis Penelitian, Sumber data, Populasi dan Sampel}

Jenis penelitian ini menggunakan metode pendekatan kuantitatif. Metode kuantitatif adalah penelitian yang berlandaskan pada filsafat positivism, digunakan untuk meneliti pada populasi atau sampel tertentu, pengumpulan data menggunakan instrument penelitian, analisis data bersifat kuantitatif/statistic, dengan tujuan untuk menguji hipotesis yang ditetapkan (Sugiyono,2014:36).

Data yang digunakan dalam penelitian ini berupa Laporan Realisasi Anggaran Pendapatan dan Belanja Daerah (APBD) periode 2012-2014 pemerintah kabupaten/kota di Provinsi Jawa Timur, yakni Pendapatan Asli Daerah, Dana Alokasi Umum, Dana Alokasi Khusus, dan Belanja Modal yang diperoleh dari website Direktorat Jendral Perimbangan Keuangan dan Produk Domestik Regional Bruto Provinsi Jawa Timur periode 2012-2014 yang diperoleh dari Badan Pusat Statistik Provinsi Jawa Timur. Populasi dalam penelitian ini adalah Pemerintah kabupaten dan kota se Jawa Timur. 
Teknik pemilihan sampel dalam penelitian ini menggunakan metode purposive sampling.

Kriteria yang harus dipenuhi dalam pemilihan sampel penelitian ini adalah:

1. Pemerintah Kabupaten dan Kota se Jawa Timur yang laporan keuangannya telah diaudit oleh BPK secara konsisten dan lengkap dari tahun 2012-2014.

2. Pemerintah Kabupaten dan Kota yang data APBD nya telah masuk dalam website Direktorat Jendral Perimbangan Keuangan Negara.

\section{Variabel Penelitian}

Variabel yang digunakan yaitu variabel bebas (independent) yaitu PAD, DAU, DAK. Variabel terikat (dependent) yaitu Pertumbuhan Ekonomi dan variabel mediasi (intervening) yaitu Belanja Modal. Dalam penelitian ini PAD, DAU, DAK dan Belanja Modal diambil dari Laporan Realisasi APBD. Sedangkan Pertumbuhan Ekonomi yang diproksi dengan PDRB diambil dari Laporan Produk Domestik Regional Bruto Kabupaten/Kota.

\section{Teknik Pengumpulan Data dan Analisis Data}

Data yang digunakan dalam penelitian ini dikumpulkan dengan menggunakan metode dokumentasi, yaitu mempelajari dokumen-dokumen ataupun data-data yang diperlukan. Alat analisis yang digunakan dalam penelitian ini adalah analisi jalur (Path Analysis). Analisis jalur digunakan untuk menguji variabel intervening. Hipotesis dalam penelitian ini dapat diuji dengan persamaan sebagai berikut:

Pertumbuhan ekonomi $=\alpha+\beta 1 \mathrm{PAD}+\beta 2 \mathrm{DAU}+\beta 3 \mathrm{DAK}+\varepsilon$

Belanja modal $=\alpha+$ p2 PAD + e1

Pertumbuhan Ekonomi $=\alpha+$ p1 PAD + P3BM + e1 


\section{HASIL PENELITIAN DAN PEMBAHASAN}

\section{HASIL PENELITIAN}

Berdasarkan uji asumsi klasik normalitas, heterokedastisitas, multikolonieritas dan autokorelasi, semua model dan persamaan dalam penelitian ini telah lolos semua uji asumsi klasik.

\section{Hasil Penelitian Persamaan satu}

Uji hipotesis yang dilakukan meliputi uji $\mathrm{R}^{2}$ atau koefisien determinasi, uji statistik $\mathrm{F}$, uji statistik t. Uji hipotesis berikut digunakan untuk menguji persamaan satu yaitu

$\mathrm{YPE}=\alpha+\beta 1 \mathrm{PAD}+\beta 2 \mathrm{DAU}+\beta 3 \mathrm{DAK}+\varepsilon$

\section{a) $\mathbf{U j i} \mathbf{R}^{2}$ atau Koefisien DeterminasiTabel}

\subsection{Uji $\mathbf{R}^{2}$ atau Koefisien Determinasi}

Model Summary

\begin{tabular}{lllll}
\hline Model & R & R Square & Adjusted R Square & Std. Error of the Estimate
\end{tabular}

1

a. Predictors: (Constant), LnDAK, LnPAD, LnDAU

b. Dependent Variable: LnPE

Sumber: Data olah SPSS

Pada tabel 4.6 di atas nilai Adjusted $R$ Square adalah 0,788. Hal ini berarti 78,8\%

YPE atau Pertumbuhan Ekonomi dapat dijelaskan oleh variabel independen yang terdiri Pendapatan Asli Daerah (PAD), Dana Alokasi Umum (DAU), Dana Alokasi Khusus (DAK). Sementara 21,2\% sisanya di pengaruhi oleh variabel di luar penelitian.

b)Uji Signifikansi atau Pengaruh Simultan (Uji Statistik F)

Tabel 4.7 Uji Statistik F

\begin{tabular}{|c|c|c|c|c|c|c|}
\hline \multicolumn{6}{|c|}{ ANOVA $^{\mathrm{a}}$} & \multirow[b]{2}{*}{ Sig. } \\
\hline & & Sum of & df & Mean & $\mathrm{F}$ & \\
\hline \multirow{3}{*}{1} & Regression & 83.193 & 3 & 27.731 & \multirow{3}{*}{$\begin{array}{r}141.38 \\
9\end{array}$} & \multirow[t]{3}{*}{$.000^{\mathrm{b}}$} \\
\hline & Residual & 21.575 & 110 & \multirow[t]{2}{*}{.196} & & \\
\hline & Total & 104.767 & 113 & & & \\
\hline
\end{tabular}

a. Dependent Variable: LnPE

b. Predictors: (Constant), LnDAK, LnPAD, LnDAU

Sumber: Data olah SPSS 
Dari tabel 4.7 di atas, nilai F hitung sebesar 141,389 dengan signifikansi 0,000. Karena nilai signifikansi berada di bawah atau lebih kecil dari 0,05 maka model regresi dapat digunakan untuk memprediksi YPE (Pertumbuhan Ekonomi). Jadi PAD, DAU, DAK secara bersama-sama berpengaruh terhadap Pertumbuhan Ekonomi.

c) Uji Signifikansi Parameter Individual (Uji Statistik t)

Tabel 4.8 Uji Statistik t

\section{Coefficients $^{\mathrm{a}}$}

\begin{tabular}{|c|c|c|c|c|c|c|}
\hline \multirow{2}{*}{\multicolumn{2}{|c|}{ Model }} & \multicolumn{2}{|c|}{$\begin{array}{c}\text { Unstandardized } \\
\text { Coefficients }\end{array}$} & $\begin{array}{l}\text { Standardized } \\
\text { Coefficients }\end{array}$ & \multirow[t]{2}{*}{$\mathrm{t}$} & \multirow[t]{2}{*}{ Sig. } \\
\hline & & $\mathrm{B}$ & Std. Error & Beta & & \\
\hline \multirow{4}{*}{1} & (Constant) & -3.326 & 1.695 & & -1.963 & .052 \\
\hline & LnPAD & .746 & .075 & .625 & 9.958 & .000 \\
\hline & LnDAU & 1.047 & .202 & .400 & 5.196 & .000 \\
\hline & LnDAK & -.282 & .086 & -.194 & -3.280 & .001 \\
\hline
\end{tabular}

a. Dependent Variable: LnPE

Sumber: Data olah SPSS

Tabel 4.8 di atas menunjukkan bahwa variabel Pendapatan Asli Daerah (PAD) mempunyai nilai signifikansi sebesar 0,000 yang jauh lebih kecil dari 0,05 hal ini menunjukkan bahwa Pendapatan Asli Daerah (PAD) berpengaruh terhadap Pertumbuhan Ekonomi. Variabel Dana Alokasi Umum (DAU) mempunyai nilai signifikansi sebesar 0,000. Nilai signifikansi ini masih jauh lebih kecil dari 0,05 hal ini menunjukkan bahwa Dana Alokasi Umum (DAU) berpengaruh terhadap Pertumbuhan Ekonomi. Sehingga hipotesis yang menyatakan bahwa Dana Alokasi Umum (DAU) berpengaruh terhadap Pertumbuhan Ekonomi diterima. Variabel Dana Alokasi Khusus (DAK) mempunyai nilai signifikansi 0,001 . Nilai signifikansi ini masih jauh lebih kecil dari 0,05 hal ini menunjukkan bahwa Dana Alokasi Khusus (DAK) berpengaruh terhadap Pertumbuhan Ekonomi. Sehingga hipotesis yang menyatakan bahwa Dana Alokasi Khusus (DAK) berpengaruh terhadap Pertumbuhan Ekonomi diterima. 


\section{Hasil Penelitian Persamaan Dua}

\subsection{Path Analysis Persamaan 2}

$$
\mathrm{YBM}=\alpha+\mathrm{p} 1 \mathrm{PAD}+\mathrm{e} 1
$$

a) Uji $\mathbf{R}^{2}$ atau Koefisien Determinasi

Tabel 4.9 Uji $\mathbf{R}^{2}$ atau Koefisien Determinasi

Model Summary

\begin{tabular}{lrrrr}
\hline Model & R & R Square & $\begin{array}{c}\text { Adjusted R } \\
\text { Square }\end{array}$ & $\begin{array}{l}\text { Std. Error of } \\
\text { the Estimate }\end{array}$ \\
\hline 1 & $.807^{\mathrm{a}}$ & .652 & .649 & .33629 \\
\hline
\end{tabular}

a. Predictors: (Constant), LnPAD

b. Dependent Variable : LnBM

Sumber : Data olah SPSS

Pada tabel 4.9 di atas nilai Adjusted $R$ Square adalah 0,649 hal ini berarti 64,9\% YBM atau Belanja Modal dapat dijelaskan oleh variabel independen yaitu Pendapatan Asli Daerah.

b) Uji Signifikan atau Pengaruh Simultan (Uji Statistik F)

Tabel 4.10 Uji Statistik F

\begin{tabular}{|c|c|c|c|c|c|c|}
\hline \multicolumn{7}{|c|}{ ANOVA $^{a}$} \\
\hline \multicolumn{2}{|c|}{ Model } & $\begin{array}{l}\text { Sum of } \\
\text { Squares }\end{array}$ & df & $\begin{array}{l}\text { Mean } \\
\text { Square }\end{array}$ & $\mathrm{F}$ & Sig. \\
\hline \multirow{3}{*}{1} & Regression & 23.728 & 1 & 23.728 & \multirow{3}{*}{$\begin{array}{r}209.81 \\
0\end{array}$} & \multirow[t]{3}{*}{$.000^{\mathrm{b}}$} \\
\hline & Residual & 12.666 & 112 & \multirow[t]{2}{*}{.113} & & \\
\hline & Total & 36.394 & 113 & & & \\
\hline
\end{tabular}

a. Dependent Variable: LnBM

b. Predictors: (Constant), LnPAD

Sumber: Data olah SPSS

Dari tabel 4.10 di atas, nilai F hitung sebesar 209,810 dengan signifikansi 0,000. Karena signifikansi jauh lebih kecil dari 0,05, maka model regresi dapat digunakan untuk memprediksi YBM (Belanja Modal). Sehingga dapat dikatakan bahwa Pendapatan Asli Daerah (PAD) berpengaruh terhadap Belanja Modal. 
c) Uji Signifikansi Parameter Individual (Uji Statistik t)

Tabel 4.11 Uji Statistik t

\begin{tabular}{|c|c|c|c|c|c|c|}
\hline \multirow{3}{*}{\multicolumn{2}{|c|}{ Model }} & \multicolumn{4}{|c|}{ Coefficients $^{\mathrm{a}}$} & \multirow{3}{*}{ Sig. } \\
\hline & & \multicolumn{2}{|c|}{$\begin{array}{l}\text { Unstandardized } \\
\text { Coefficients }\end{array}$} & \multirow{2}{*}{$\begin{array}{c}\begin{array}{c}\text { Standardized } \\
\text { Coefficients }\end{array} \\
\text { Beta }\end{array}$} & \multirow[t]{2}{*}{$\mathrm{T}$} & \\
\hline & & $\mathrm{B}$ & $\begin{array}{l}\text { Std. } \\
\text { Error }\end{array}$ & & & \\
\hline \multirow{2}{*}{1} & (Constant) & 5.565 & .470 & & 11.849 & .000 \\
\hline & LnPAD & .568 & .039 & .807 & 14.485 & .000 \\
\hline
\end{tabular}

a. Dependent Variable: LnBM

Sumber: Data olah SPSS

Tabel 4.11 di atas menunjukkan bahwa variabel Pendapatan Asli Daerah (PAD) mempunyai nilai signifikansi 0,000 yang jauh lebih kecil dari 0,05 . Hal ini menunjukkan bahwa Pendapatan Asli Daerah (PAD) berpengaruh terhadap Belanja Modal.

\subsection{Path Analysis Persamaan 3}

$\mathrm{YPE}=\alpha+\mathrm{p} 1 \mathrm{PAD}+\mathrm{p} 3 \mathrm{BM}+\mathrm{e} 2$

a) Uji $\mathbf{R}^{2}$ atau Koefisien Determinasi

Tabel 4.12 Uji $\mathbf{R}^{2}$ atau Koefisien Determinasi

\section{Model Summary}

Model R R Square Adjusted R Std. Error of

\begin{tabular}{lrrrr} 
& & \multicolumn{2}{c}{ Square } & the Estimate \\
\hline 1 & $.874^{\mathrm{a}}$ & .765 & .760 & .47134 \\
\hline
\end{tabular}

a. Predictors: (Constant), LnBM, LnPAD

b. Dependent Variable: LnPE

Sumber: Data olah SPSS

Pada table 4.12 di atas nilai Adjusted R Square adalah 0,760 hal ini berarti 76\% YPE atau Pertumbuhan Ekonomi dapat dijelaskan oleh variabel independen yang terdiri dari Pendapatan Asli Daerah (PAD) dan Belanja Modal. 
b) Uji Signifikansi atau Pengaruh Simultan (Uji Statistik F)

Tabel 4.13 Uji Statistik F

\begin{tabular}{|c|c|c|c|c|c|c|}
\hline \multicolumn{7}{|c|}{ ANOVA $^{a}$} \\
\hline \multicolumn{2}{|c|}{ Model } & $\begin{array}{l}\text { Sum of } \\
\text { Squares }\end{array}$ & df & Mean Square & $\mathrm{F}$ & Sig. \\
\hline \multirow{3}{*}{1} & Regression & 80.107 & 2 & 40.054 & 180.288 & $.000^{\mathrm{b}}$ \\
\hline & Residual & 24.660 & 111 & .222 & & \\
\hline & Total & 104.767 & 113 & & & \\
\hline
\end{tabular}

a. Dependent Variable: LnPE

b. Predictors: (Constant), LnBM, LnPAD

Sumber: Data olah SPSS

Dari tabel 4.13 di atas, nilai F hitung sebesar 180,288 dengan signifikansi 0,000.

Karena signifikansi jauh lebih kecil dari 0,05, maka model regresi dapat digunakan untuk memprediksi YPE atau Pertumbuhan Ekonomi. Jadi Pendapatan Asli Daerah (PAD) dan Belanja Modal secara bersama-sama berpengaruh terhadap Pertumbuhan Ekonomi.

c) Uji Signifikan Parameter Individual (Uji Statistik t)

Tabel 4.14 Uji Statistik t

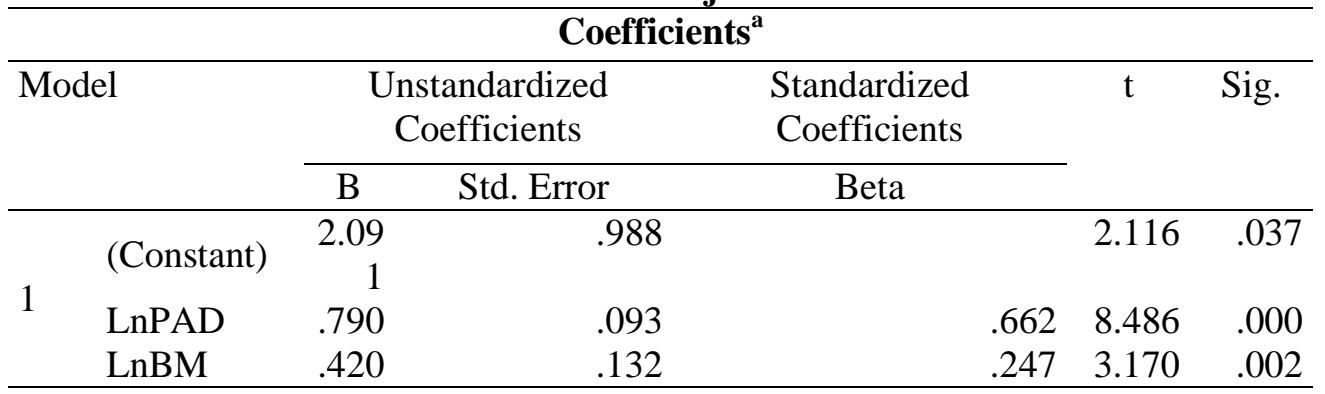

a. Dependent Variable: LnPE

Sumber: Data olah SPSS

Tabel 4.14 di atas menunjukkan bahwa variabel Pendapatan Asli Daerah (PAD) memiliki nilai signifikansi sebesar 0,000. Nilai signifikansi ini jauh lebih kecil dari 0,05 yang berarti Pendapatan Asli Daerah (PAD) berpengaruh terhadap Pertumbuhan Ekonomi. Variabel Belanja Modal pada tabel di atas memiliki nilai signifikansi sebesar 0,002. Nilai signifikansi ini jauh lebih kecil dari 0,05 yang berarti Belanja Modal berpengaruh terhadap Pertumbuhan Ekonomi. Hasil output SPSS memberikan nilai unstandardized beta Pendapatan Asli Daerah (PAD) pada persamaan 2 sebesar 0,568 dan 
signifikansi pada 0,000 yang berarti Pendapatan Asli Daerah (PAD) mempengaruhi Belanja Modal. Nilai koefisien unstandardized beta 0,568 merupakan nilai path atau jalur p2. Pada output SPSS persamaan 3 nilai unstandardized beta untuk Pendapatan Asli Daerah (PAD) sebesar 0,790 dan Belanja Modal sebesar 0,420 dan semuanya signifikan. Nilai unstandardized Pendapatan Asli Daerah (PAD) 0,790 merupakan nilai path atau jalur p1 dan nilai unstandardized beta Belanja Modal 0,420 merupakan nilai path atau jalur p3. Besarnya nilai e1 $=\sqrt{ }(1-0,652)=0,589$ dan besar nilai e2 $=\sqrt{ }(1-0,765)=0,484$.

Hasil analisis jalur menunjukkan bahwa Pendapatan Asli Daerah (PAD) dapat berpengaruh langsung ke Pertumbuhan Ekonomi dan dapat juga berpengaruh tidak lansung yaitu dari Pendapatan Asli Daerah ke Belanja Modal (sebagai intervening) lalu ke Pertumbuhan Ekonomi.

\section{PEMBAHASAN}

\section{Pengaruh Pendapatan Asli Daerah (PAD) terhadap Pertumbuhan Ekonomi}

Hasil penelitian ini adalah Pendapatan Asli Daerah (PAD) berpengaruh positif dan signifikan terhadap Pertumbuhan Ekonomi. Otonomi daerah memberikan wewenang sepenuhnya kepada pemerintah daerah untuk mengatur dan mengelola sendiri pendapatannya termasuk Pendapatan Asli Daerah (PAD). Pendapatan Asli Daerah (PAD) merupakan salah satu sumber pendapatan yang berfungsi untuk membiayai kebutuhan daerah tersebut seperti pembangunan infrastruktur dan sarana prasarana. Laju perekonomian di suatu daerah juga dipengaruhi oleh sarana prasarana di daerah tersebut, semakin baik fasilitas sarana dan prasarana di daerah tersebut maka akan berpengaruh terhadap laju pertumbuhan ekonomi di daerah tersebut.

\section{Pengaruh Dana Alokasi Umum (DAU) terhadap Pertumbuhan Ekonomi}

Hasil penelitian ini adalah Dana Alokasi Umum (DAU) berpengaruh positif dan signifikan terhadap Pertumbuhan Ekonomi. Hibah ini dapat digunakan untuk banyak 
tujuan sesuai dengan kebutuhan. Sehingga Dana Alokasi Umum (DAU) ini salah satu dana perimbangan yang dapat digunakan untuk melakukan pembangunan infrastruktur dan sarana prasarana di daerah tersebut. Dan diharapkan dari pembangunan tersebut dapat berdampak terhadap laju Pertumbuhan Ekonomi di daerah tersebut agar tidak terjadi ketimpangan fiskal.

\section{Pengaruh Dana Alokasi Khusus (DAK) terhadap Pertumbuhan Ekonomi}

Hasil penelitian ini adalah Dana Alokasi Khusus (DAK) berpengaruh terhadap Pertumbuhan Ekonomi tetapi kearah negatif. Dana Alokasi Khusus (DAK) adalah salah satu mekanisme transfer keuangan pemerintah pusat ke daerah yang bertujuan antara lain untuk meningkatkan penyediaan sarana dan prasarana fisik daerah sesuai prioritas nasional serta mengurangi kesenjangan laju pertumbuhan antar daerah dan pelayanan antar bidang (Ahmad Subekan, 2012:88). Salah satu contoh kebutuhan khusus dan merupakan urusan daerah dan juga prioritas nasional antara lain : kebutuhan transmigrasi, kebutuhan beberapa jenis investasi atau prasarana, pembangunan jalan di kawasan terpencil, saluran irigrasi primer. Tetapi perlu diketahui bahwa tidak semua daerah menerima Dana Alokasi Khusus (DAK), karena Dana Alokasi Khusus (DAK) bertujuan untuk pemerataan dan untuk meningkatkan kondisi infrastruktur fisik yang dinilai sebagai prioritas nasional. Sehingga Dana Alokasi Khusus (DAK) suatu daerah semakin tinggi tidak selalu semakin tinggi pula laju Pertumbuhan Ekonomi di daerah tersebut. Karena Dana Alokasi Khusus (DAK) hanya digunakan untuk membiayai pembangunan yang menjadi kebutuhan daerah dan yang merupakan prioritas nasional.

\section{Pengaruh Pendapatan Asli Daerah (PAD) terhadap Pertumbuhan Ekonomi dengan}

\section{Belanja Modal sebagai Variabel Intervening}

Hipotesis keempat menguji apakah pengaruh Pendapatan Asli Daerah (PAD) terhadap Pertumbuhan Ekonomi dengan Belanja Modal sebagai variabel intervening. Hasil pengujian path analysis menunjukkan bahwa Belanja Modal dapat menjadi variabel 
mediasi (intervening) antara Pendapatan Asli Daerah (PAD) dan Pertumbuhan Ekonomi. Dari hasil diatas dapat dilihat jika terjadi mediasi parsial karena nilai t hitung lebih rendah dari nilai $t$ tabel.

Adanya kebijakan otonomi daerah bertujuan agar setiap daerah mampu memaksimalkan potensi daerahnya sehingga dapat meningkatkan Pendapatan Asli Daerah (PAD). Dalam penyusunan APBD pemerintah daerah akan mengalokasikan Belanja Modal disesuaikan dengan mempertimbangkan jumlah Pendapatan Asli Daerah (PAD) yang diperoleh. Oleh sebab itu Pendapatan Asli Daerah berpengaruh positif terhadap Belanja Modal. Semakin tinggi Pendapatan Asli Daerah (PAD) suatu daerah semakin tinggi pula Belanja Modal, semakin tinggi Belanja Modal semakin tinggi pula Pertumbuhan Ekonomi. Sehingga suatu daerah yang memiliki tingkat Pendapatan Asli Daerah (PAD) yang tinggi harus mengalokasikan Pendapatan Asli Daerah (PAD) tersebut ke dalam anggaran Belanja Modal yang lebih besar. Karena semakin besar anggaran Belanja Modal di suatu daerah maka semakin tinggi pula laju Pertumbuhan Ekonomi. Hal ini disebabkan karena manfaat dan kegunaan Belanja Modal sangat berpengaruh terhadap Pertumbuhan Ekonomi.

\section{SIMPULAN}

\section{Simpulan}

Berdasarkan hasil pengujian yang dilakukan dapat disimpulkan:

1. Pendapatan Asli Daerah (PAD) berpengaruh terhadap besarnya Pertumbuhan Ekonomi dengan nilai positif.

2. Dana Alokasi Umum (DAU) berpengaruh terhadap besarnya Pertumbuhan Ekonomi dengan nilai positif.

3. Dana Alokasi Khusus (DAK) berpengaruh terhadap besarnya Pertumbuhan Ekonomi dengan nilai negatif. 
4. Belanja Modal dapat menjadi variabel mediasi (intervening) antara Pendapatan Asli Daerah (PAD) dan Pertumbuhan Ekonomi.

\section{Saran}

Berdasarkan hasil penelitian yang telah dilakukan maka peneliti memberikan saran sebagai berikut: Hasil penelitian ini dapat menjadi pertimbangan Pemerintah Daerah dalam mengalokasikan Pendapatan Asli Daerah (PAD) ke dalam Belanja Modal karena manfaat dan kegunaan Belanja Modal berkaitan erat dengan laju Pertumbuhan Ekonomi. 


\section{Daftar Pustaka}

Abdullah, 2012. "Economic Growth and its Determinants: a Longitudinal and a Crossregional Analysis”. Journal of Economics and Sustainable Development Vol.3, No.1

Abdullah, S. dan Halim, Abdul, 2003. "Pengaruh Dana Alokasi Umum dan Pendapatan Asli Daerah Terhadap Belanja Pemerintah Daerah (studi kasus kabupaten/kota di Jawa dan Bali)”. Jurnal Ekonomi STEI No.2, Tahun XIII/25

Adi, Priyo Hadi. 2006. "Hubungan Antara Pertumbuhan Ekonomi Daerah, Belanja Pembangunan dan Pendapatan Asli Daerah (Studi pada Kabupaten dan Kota se Jawa dan Bali)". Simposium Nasional Akuntansi IX. Padang.

BPS Provinsi Jawa Timur. 2015. Produk Domestik Regional Bruto Kabupaten/Kota Menurut Lapangan Usaha. Surabaya.

Darwanto dan Yustikasari, Yulia. 2007. "Pengaruh Pertumbuhan Ekonomi, Pendapatan Asli Daerah dan Dana Alokasi Umum Terhadap Pengalokasian Anggaran Belanja Modal”. Simposium Nasional Akuntansi X. Makassar.

Ghozali, Imam. 2012. Aplikasi Analisis Multivariate Dengan Program Ibm SPSS 20. Semarang: Badan Penerbit Universitas Diponegoro.

Halim, Abdul. 2014. Akuntansi Sektor Publik; Akuntansi Keuangan Daerah. Jakarta : Salemba Empat.

Harianto, David dan Adi, Priyo Hari. 2007. "Hubungan Antara Dana Alokasi Umum, Belanja Modal, Pendapatan Asli Daerah dan Pendapatan Perkapita”. Simposium Nasional Akuntansi X. Makassar.

Liliana, Bunescu, Mihaiu Diana dan Comaniciu Carmen. 2011. "Is There a Correlation between Goverment Expenditurs, Population, Money Supply, and Goverment Revenues?". International Journal of Arts and Sciences, Vol.4(12):pp 241-254.

Mardiasmo. 2009. Akuntansi Sektor Publik. Yogyakarta : Penerbit Andi. 
Mawarni dan Darwanis. 2013. "Pengaruh Pendapatan Asli Daerah dan Dana Alokasi Umum Terhadap Belanja Modal serta Dampaknya Terhadap Pertumbuhan Ekonomi Daerah (Studi Kasus pada Kabupaten dan Kota di Aceh)”. Jurnal Pasca Sarjana Universitas Syiah Kuala. Vol. 2(2) Hal:80-90.

M. L. Jhingan. 2010. Ekonomi Pembangunan dan Perencanaan. Jakarta : Raja Grafindo Persada.

Palealu, Andreas Marzel. 2013. "Pengaruh Dana Alokasi Khusus (DAK), dan Pendapatan Asli Daerah (PAD) terhadap Belanja Modal Pemerintah Kota Manado tahun 20032012”. Jurnal Riset Ekonomi, Manajemen, dan Akuntansi, Vol.1(4):hal 1165-1284

Sugiyono. 2014. Metode Penelitian Kuantitatif Kualitatif dan R\&D. Bandung: Alfabeta.

Suhendra, Made Dwi Septiadi, Ni Luh Gede Erni Sulindawati dan Made Pradana Adiputra. 2015. "Pengaruh Dana Alokasi Umum (DAU), Dana Alokasi Khusus (DAK), dan Belanja Pemeliharaan terhadap Pengalokasian Anggaran Belanja Modal pada Kabupaten/Kota di Bali Periode 2009-2013”. E-journal S1 AkUniversitas Pendidikan Ganesha, Vol.3(1)

Sukirno, Sadono. 2004. Makro Ekonomi Teori Pengantar. Jakarta : Raja Grafindo Persada.

Sukirno, Sadono. 2006. Mikro Ekonomi Teori Pengantar. Jakarta : Raja Grafindo Persada.

Sutedi, Adrian. 2012. Hukum Keuangan Negara. Jakarta : Sinar Grafika

Taiwo, Muritala dan Taiwo Abayomi. 2011. "Goverment Expenditure and Economic Development: Empirical Evidence from Nigeria”. European Journal of Business and Management, Vol.3(9).

Todaro, Michael P dan Smith, Stephen C. 2006. Pembangunan Ekonomi. Terjemahan Haris Munandar. Jakarta: Penerbit Erlangga. 